Egypt. Poult. Sci. Vol. (41) (II): (333-349)(2021)

Egyptian Poultry Science Journal

http://www.epsj.journals.ekb.eg/

ISSN: 1110-5623 (Print) - 2090-0570 (Online)

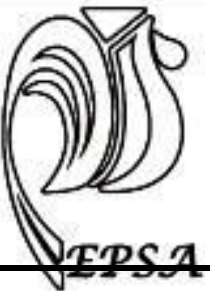

\title{
EFFECT OF IN-OVO INJECTION OF BIOTIN, AND CARNITINE ON HATCHING AND GROWTH PERFORMANCE IN BROILER CHICKS
}

\author{
Sara Kh. Sherif; Ismail, F. S. A; Elbasil, E. I.; kalaba, Z. M \\ Poult. Prod. Dep., Fac. of Agric., Mansoura Uni.
}

Corresponding author: Sara Khalil Sherif, E-mail: sarasherif349@ yahoo.com

Received: 18/04/2021 Accepted: 06/06/2021

\begin{abstract}
This study investigated the effect of injecting biotin, and carnitine in hatching eggs at four incubation times on hatchability traits and subsequent broiler chick's performance. The eggs were injected with $0.1 \mathrm{ml}$ biotin or carnitine compared to of saline (placebo control) at 1, 14, 16, 18 days of incubation. Thereafter, bird's growth performance was monitored.

The obtained results show that the highest fertile hatchability percent was achieved by saline water followed by biotin and carnitine injection. The best fertile hatchability percent recorded with the injection at day 18 followed by day 14, day 16 of incubation. Biotin followed by carnitine injection significantly improved final live body weight of chicks compared to saline water. Also, biotin injection significantly showed the best feed conversion ratio. Injection time had no significant effect on growth performance and carcass traits. It is suggested that the eggs injection with biotin or L-Carnitine at the day $18^{\text {th }}$ of incubation could improve hatchability and subsequent broiler growth performance.
\end{abstract}

Key Words: Biotin, L-Carnitine, injection, Hatchability, Broilers, Growth performance. 
Sara Kh. Sherif et al.

\section{INTRODUCTION}

Injecting eggs technique is used to provide nutrients to develop embryo and improve subsequent growth performance leading to more benefits to poultry producers (Bhanja et al. 2008). Biotin is important water-soluble vitamin for poultry. Also, it has important roles in metabolic processes (Calnek et al., 1997). Robel (2002) found that injection of turkey eggs with $87 \mu \mathrm{g} / \mathrm{egg}$ biotin at day 25 of incubation resulted in approximately $4.6 \%$ higher hatchability than the control group. Memon et al. (2014) found that weight gain of broilers was increased, and feed conversion was improved with increasing the level of biotin supplementation in broiler ration. Similarly, Vieira (2007) found that injection of turkey eggs with biotin, folic acid, and pyridoxine led to an improvement in hatchability of eggs. Also, Ahmed et al. (2017) reported that injection time of biotin had significant effects on hatchability traits. However, in turkey in ovo administration of biotin on day 24 of incubation was more efficient than the other injection time. In ovo biotin especially at late embryonic life (24 of incubation) improve gluconeogenesis during embryonic life and consequently this vitamin contributes to such important processes as reproduction, bone development and growth therefore, it is probable that the most optimal time for the introduction of biotin into turkey eggs with the aim of improving hatchability during the period $21^{\text {th }}$ and $25^{\text {th }} \mathrm{d}$ of incubation.

L-Carnitine is a water-soluble quaternary amine. Bremer (1983) reported that Lcarnitine capacities as a basic acyl carrier within the mitochondrial betaoxidation of long-chain fatty acids to produce energy. Shafey et al. (2010) reported that injected eggs with carnitine ( 25 up to $500 \mu \mathrm{g} / \mathrm{egg}$ ) increased hepatic and pectoral muscle glycogen contents of hatched chicks. Also, Salmanzadeh et al. (2012) showed that in ovo injection with carnitine positively affected carcass traits of chicks. In this respect, Lettner et al. (1992) observed that the fatty acid composition of abdominal fat was significantly modified in response to feeding carnitine-supplemented diets in broiler chickens. In addition, $\mathrm{Xu}$ et al. (2003) demonstrated that supplementation with carnitine in broiler diet enhanced breast meat yield and its lipid content and reduced abdominal fat. The present study was conducted to investigate the response in terms of hatchability traits and growth performance of fertile eggs and hatched chicks, respectively upon in ovo injection of biotin, and L-carnitine at the rate of $0.1 \% \mathrm{ml} / \mathrm{egg}$ at four incubation times (day $1,14,16$ or 18 ).

\section{MATERIALS AND MEHTODES}

Injecting eggs with biotin, L-carnitine, and saline (control) was carried out in a commercial hatchery in Dakahlia Governorate Egypt, the hatching chicks were reared at the private open sided poultry farm during 2018 . The laboratory analyses were performed at laboratories of Faculty of Agriculture Mansoura University.

\section{Egg injection and incubation:}

In this study, eggs were injected with two tested solutions of biotin or L-carnitine $v s$. saline water at the rate of $0.1 \mathrm{ml} / \mathrm{egg}$. Injections were made at 1, 14, 16, 18 days of incubation. Treatments were prepared as follows: Biotin $1.5 \mathrm{mg} / 100 \mu \mathrm{l}$ sterile saline and L-carnitine $8 \mathrm{mg} / 100 \mu \mathrm{l}$ sterile saline. A total of 1,800 eggs were used in that trial and were produced from 62week-old broiler breeders (Cobb-500). 
Biotin, L-Carnitine, injection, Hatchability, Broilers, Growth performance.

For each injection time, $25 \%$ of these eggs (450 eggs) were divided into three equal groups. The eggshell of each group was carefully clicked at the wide end of the egg then injected with specified solutions in air sac area (at a depth of 5 $\mathrm{mm}$ ) by a team of supervising members and operators with experience using insulin syringes, according to the following procedure: 150 eggs were injected with sterile saline, 150 eggs were injected with biotin, and 150 eggs were injected with L-carnitine. To avoid crosscontamination among eggs of different treatments, the used insulin syringes had been changed repeatedly with new ones after performing five injections. The injection sites of eggs were disinfected with ethyl alcohol and sealed using adhesive cellophane and transferred again to the same incubator (a single-stage incubator equipped with a system of automatic turning for eggs) to complete the embryonic development and hatching process, according to specified hatchery practices (incubator temperature and relative humidity were maintained at $37.6^{\circ} \mathrm{C}$ and $52 \%$ from day one to day 18 of incubation but during the last three days of the incubation period, the temperature was decreased to $36.9^{\circ} \mathrm{C}$ coincided with relative humidity values of 60,75 and $80 \%$ for the $19^{\text {th }}, 20^{\text {th }}$ and $21^{\mathrm{st}}$, respectively). All hatched chicks were used to calculate the hatchability of fertile or total set eggs.

Hatching chicks of each experimental group were divided into three replications; all chicks weighed and received the starter diet from hatch up to 21 days of age, then grower diet till the end of the growing experiment at 5 weeks of age. The birds reared under the same conditions. The light program was $23 \mathrm{~h}$ photoperiod and $1 \mathrm{~h}$ darkness. The diets and water were offered ad libitum. Both starter and grower diets, applied herein, were formulated to meet the nutrient requirements of broiler chicks, as recommended by the National Research Council (NRC, 1994). Ingredient composition and calculated analyses of these basal starters and grower diets are shown in Table 1.

\section{Chicken growth performance:}

Chicken's weight (LBW) and feed intake (FI) were weekly recorded at replicate basis for hatched chicks from eggs injected with saline, biotin and Lcarnitine. Body weight gain (BWG) and feed conversion (FCR) were calculated. The cumulative means of LBW, FI, BWG, and FCR were calculated for the whole experimental period (0-35 days of age). The mortality of chicks was also monitored throughout the feeding trial.

\section{Carcass traits of broiler chicks:}

At the end of the study (35 days of age), 12 chicks from each treatment, of approximately similar body weights were slaughtered. Feed was withdrawn for 12 h. before slaughtering. Individual LBW of birds was recorded immediately before slaughtering. Carcass traits were recorded. Procedures for cleaning out were performed on the hot carcasses. Weights of carcass yield (CY) and edible organs were determined. The cutting up of carcasses was made according to Jensen (1984). Carcass yield and its components and the edible organs were expressed as a percentage of live body weight at slaughter.

\section{Plasma blood parameters}

At hatch, 12 chicks from each treatment were chosen to collect 12 plasma blood samples. The plasma was separated by centrifugation process at $3000 \mathrm{rpm}$ for 15 minutes. Plasma concentrations of total protein, glucose, cholesterol, high-density 
Sara Kh. Sherif et al.

lipoprotein cholesterol, Low-density lipoprotein, GOT and GPT were measured by commercial kits (commercial kits: Spectrum Diagnostic kits S.A.E., Egyptian company of biotechnology, 2016).

At the end of the growing experiment (35 days of age) 12 birds from each treatment were chosen to collect blood samples in heparinized tubes. Plasma blood samples were obtained by centrifugation process to determine total protein, glucose, cholesterol, high-density lipoprotein cholesterol, Low-density lipoprotein, GOT and GPT were measured by commercial kits (commercial kits: Spectrum Diagnostic kits S.A.E., Egyptian company of biotechnology, 2016).

\section{Statistical analysis}

The statistical processing of results was performed by using two-way analysis of variance of the GLM procedure of the Statistical Analysis System (SAS, 2004). Differences between means of different variables were alienated by Duncan's new Multiple Range Test at $\mathrm{P} \leq 0.05$ (Duncan, 1955). The following statistical model was used: $Y i j=\mu+E i+T j+E T i j+e i j$. Where: Yij $=$ observed traits; $\mu=$ the overall mean; $\mathrm{Ei}=$ effect of injection materials; $\mathrm{i}=(1,2$ and 3$) ; \mathrm{Tj}=$ effect of injection time; $\mathrm{j}=(1,2,3$ and 4$) ; \mathrm{ETij}=$ effect of interaction between injection materials and injection time; eij = experimental random error.

\section{RESULTS AND DISCUSSION} Reproductive performance:

Data summarized in Table 2 show hatchability and hatching chick weight as influenced by in ovo injection with saline, biotin and L-carnitine at four incubation ages and their interaction. Total set hatchability and chick hatching weight were not affected $(\mathrm{P}>0.05)$ by injection materials in eggs, but there were significantly affected $(\mathrm{P} \leq 0.01)$ by injection time. However, the fertile hatchability was significantly affected $(\mathrm{P} \leq 0.01)$ by injection materials and injection time and interaction. The highest value of fertile hatchability was achieved by biotin injection followed by L-carnitine without significant differences between them. Fertility percent was significant affected by injection materials, whereas injection by saline recorded the lowest fertility value comparing with biotin and L-carnitine injection materials. The highest value of total hatchability regarding total set eggs was achieved by injection at $18^{\text {th }}$ followed by $14^{\text {th }}, 16^{\text {th }}$ and 1 day of incubation. Injections at $18^{\text {th }}$ day of incubation was achieved the highest value of fertile hatchability followed by day $14^{\text {th }}, 16^{\text {th }}$ and 1 day of incubation in descending order. Chicks from eggs injected at $14^{\text {th }}$ day of incubation showed lower wight comparing with those hatched from eggs injected at $18^{\text {th }}, 16^{\text {th }}, 1$ day of incubation. Interaction between injection materials and time of injection were significantly affected on total set hatchability, fertile hatchability and fertility but were not affected on hatching chick weight.

Ahmed et al. (2017) reported that injection time of biotin had significant effects on hatchability traits. However, in turkey in ovo administration of biotin on day 24 of incubation was more efficient than the other injection time. In ovo biotin especially at late embryonic life (day 24 of incubation) improve gluconeogenesis during embryonic life and consequently this vitamin contributes to such important processes as reproduction, bone development and growth therefore, it is probable that the most optimal time for 
Biotin, L-Carnitine, injection, Hatchability, Broilers, Growth performance.

the introduction of biotin into turkey eggs with the aim of improving hatchability during the period $21^{\text {th }}$ and $25^{\text {th }} \mathrm{d}$ of incubation. Abdulateef and Al-Bayar (2013) reported that chick weight was superior by injecting $75 \mu \mathrm{g}$ biotin at age of 1 and 18 day of incubation. Ibrahim et al. (2012) and Bhanja et al. (2007) found that chicken eggs injected with $100 \mu \mathrm{g}$ $\mathrm{B}_{6} /$ egg on day 14 of incubation increased hatchability. McMahon (2002) reported that injected biotin into turkey eggs increased hatchability during the period 21 and $25^{\text {th }} \mathrm{d}$ of incubation. Also, Robel (2002) found that hatchability of turkey eggs was increased by injection biotin. Our results are in harmony with those of Shafey et al. (2010), who found that improvement in chick weight at hatch and did not affected hatchability of eggs injected with carnitine.

In contrary with our results, Dooley et al. (2011) found that hatchability of broiler chicks was not affected by injecting eggs with carnitine. Keralapurath et al. (2010a) and Nouboukpo et al. (2010) showed that injecting L-carnitine in broiler eggs did not affect hatchability traits. Zhai et al. (2008) indicated that injecting L-carnitine into fertile chicken eggs at 17 or 18 days of incubation, did not affect hatchability or hatch weight of chicks. However, Keralapurath et al. (2010b) reported that carnitine injection into broiler breeder eggs negatively affected the hatchability traits.

\section{Broiler performance:}

Data in Table 3 show that total BWG, FI and FCR of broiler fed respective diets affected by injection with saline, biotin and L-carnitine in ovo at four different ages. Also, the effect of interaction between injection materials and the injection time on broiler performance. The highest final body weight was recorded for chicks hatched from eggs injected by biotin compared with Lcarnitine and control group. The injection time was not affected on marketing weight. Weight gain of chicks was significantly affected by injection materials, where the best body weight gain for biotin group, followed by Lcarnitine and finally for saline (control); however, weight gain was not affected by injection time. Total feed intake was not affected by injection material or injection time. During fattening period, feed conversion ratio was significantly better for biotin group compared with Lcarnitine and saline experimental groups. Feed conversion ratio was not affected by injection time. The interactions between the injection materials and injection time were insignificant effect on total growth performance of broiler.

Our results partially agree with the Ahmed et al. (2017), who reported that turkey chicks' weight was improved by injected biotin at the final incubation compared to control group. Abdulateef and Al-Bayar (2013) reported that chick weight at hatch increased by injection eggs with biotin at 1 and 18 day of incubation. Biotin is an essential coenzyme for all known organisms (McMahon, 2002). Its physiologically active form is linked to enzymes of great metabolic process like biotin carboxylase and biotin decarboxylase and a coenzyme in important processes like gluconeogenesis and fatty acids and protein synthesis and consequently this vitamin contributes to such important processes as reproduction, bone development and growth. Salmanzadeh et al. (2013) found that carnitine infused eggs led to improvements of weights, feed consumed and feed utilization of turkey poults compared with the control 
Sara Kh. Sherif et al.

group. Dooley et al. (2011) who reported that feed consumption decreased by injected L-carnitine of $32 \mathrm{mg} / 100 \mu \mathrm{l}$ in ovo broiler chicks.

Also, Keralapurath et al. (2010a) found that FI, FCR and mortality were not affected by injection broiler eggs with carnitine. Moreover, Sarica et al. (2005) found that Japanese quail FI and BWG were not affected by feeding diets enriched with carnitine. Xu et al. (2003) indicated that daily BWG and FCR of broilers were not affected with feeding diets enriched with carnitine. Also, Barker and Sell (1994) concluded that LBW and FCR of broiler or turkey were not affected by feeding diets enriched with carnitine.

\section{Carcass traits of broiler chicks:}

Table 4 shows that the effect of the type of egg injected with saline, biotin and LCarnitine at different time during incubation and their interaction on the carcass characteristics of broiler chickens (Cobb-500). The carcass parts percentages were not significantly differed between the experimental treatments by injection material or injection time. Also, there were no significant differences due to the interaction between the type of injection material and injection times. In the same meaning, Dooley et al. (2011) found that carcass weight of broiler chicks was not significantly affected by injecting carnitine in eggs of broiler breeder. Similar results were found by Keralapurath et al. (2010a), who reported that injecting eggs by L-carnitine did not alter carcass characteristics of turkey poults. Also, Sarica et al. (2005) showed that feeding L-carnitine-supplemented diets had no effect on carcass yields and the relative values of giblets in Japanese quail. Barker and Sell (1994) reported that feeding diets enriched by carnitine did not affect breast meat yield or carcass components of either broiler chickens or young turkey.

On the other hand, Parsaeimehr et al. (2014), who observed that thigh meat and breast muscle percentages increased, however, abdominal fat percentage decreased in broiler chicks by dietary Lcarnitine. In addition, Oladele et al. (2011) evaluated the effect of carnitine administration on carcass traits of broiler chickens and found a significant increase in dressing percentage, breast meat and back weight while abdominal fat was reduced. $\mathrm{Xu}$ et al. (2003) reported that added L-carnitine in broiler diets caused a significant increase in breast yield and decreased the abdominal fat content. Thigh meat yield increased but abdominal fat was reduced in broiler chicks fed Lcarnitine-supplemented diets (Rabie et al., 1997; Rabie and Szilagyi, 1998).

\section{Blood parameters of day-old broiler chicks:}

Date of blood plasma constituents (glucose - total protein - total cholesterol -HDL - LDL - GPT - GOT) of one-dayold broiler chicks as affected by in ovo injection during incubation by the experimental materials at different times and their interaction are present in Table 5. All blood plasma components were not significantly affected by injection materials. Injection times had significantly affected some blood plasma parameters (glucose - total protein - HDL - GOT), however, total cholesterol, LDL and GPT did not significantly affected by injection time. Blood plasma glucose was significantly increased by injection at $1^{\text {st }}$ day of incubation compared with other injection times. Total protein value at the $1^{\text {st }}$ day was significantly higher than values at days $16^{\text {th }}$ and $18^{\text {th }}$, but 
Biotin, L-Carnitine, injection, Hatchability, Broilers, Growth performance.

statistically equaled with value at $14^{\text {th }}$ day of injection time. HDL and GOT values at the $1^{\text {st }}$ and $14^{\text {th }}$ days were significantly higher comparing with the values at days of $16^{\text {th }}$ and $18^{\text {th }}$ of injection time. The results indicated that the interaction between injection materials and injection time was significant only for HDL while the other plasma blood parameters were not affected.

Blood plasma constituents (glucose - total protein - total cholesterol - HDL - LDL GPT - GOT- total lipid- $\mathrm{T}_{3}-\mathrm{T}_{4}$ ) are presented in Table 6. Plasma constituents were not significantly affected by injection materials except for LDL, total lipid, $\mathrm{T}_{3}$ and $\mathrm{T}_{4}$. Where LDL values were high by injection of saline or L-carnitine than biotin. Total lipids values were decreased by L-carnitine injection compared with both saline and biotin. $\mathrm{T}_{3}$ was increased by biotin injection comparing with saline, but there were no significant differences between $\mathrm{T} 3$ value of L-carnitine group and biotin or saline groups. T4 values were increased by biotin and L-carnitine injection comparing with saline group.

Regarding to in ovo injection time during incubation, plasma constituents of broiler chicks were significantly affected by injection time except total protein, cholesterol and GPT. The highest value of plasma glucose for group injected at day 14 of incubation followed by day 16 , but there were no significant differences between groups injected at day1, 16 or 18 of incubation. Total lipids (TL) and lowdensity lipoprotein (LDL) values were significantly increased at days of $14^{\text {th }}$, $16^{\text {th }}$, and $18^{\text {th }}$ comparing to day $1^{\text {st }}$ of injection. High density lipoprotein (HDL) was significantly increased by injection at $1^{\text {st }}$ day compared with other injection times at $14^{\text {th }}, 16^{\text {th }}, 18^{\text {th }}$ day of incubation. The GOT values were significantly higher by injection at the first and the day $14^{\text {th }}$ comparing with the day $18^{\text {th }}$, however no significant differences among values of injection at days $1^{\text {st }}, 14^{\text {th }}$ and $16^{\text {th }}$ of incubation. Triiodothyronine (T3) was increased by injection at the day $16^{\text {th }}$ comparing with days $14^{\text {th }}$ and $18^{\text {th }}$ of incubation, however no significant differences were detected between values at the $1^{\text {st }}$ and $16^{\text {th }}$ or among values at the first, $14^{\text {th }}$ and $18^{\text {th }}$ of incubation. Thyroxine (T4) values were significantly increased by injection at the day $14^{\text {th }}$ compared with values at the first day and the day $16^{\text {th }}$ of incubation. No significant differences were found in thyroxine values by injection at the day $14^{\text {th }}$ and $18^{\text {th }}$ of incubation. The interaction between injection materials and injection time during incubation was not significant in blood plasma measurements except for total protein, total lipid, LDL, T3 and T4.

Our results concur with the findings of Ahmed et al. (2017). They found that serum total protein, total lipid, cholesterol, triglyceride and triiodothyronine were improved by injection of biotin $(75$ and $100 \mu \mathrm{g} / \mathrm{egg}$ in 24-day of incubation) of turkey chicks. Abdel-Fattah et al. (2014) found that dietary supplementation with L-carnitine produced significant reduction in serum concentrations of total lipid, cholesterol, triglycerides, low density lipoprotein and malondialdehyde in Japanese quail. Abdulateef and Al-Bayar (2013) reported that plasma total protein and total lipid in broiler chicks improved by injected biotin compared with control group. In addition, Wang et al. (2013) reported that dietary L-carnitine supplementation reduced serum levels of triglyceride and glucose and increased serum levels of total 
Sara Kh. Sherif et al.

protein and globulin in broiler chicks. Rezaei et al. (2007) demonstrated that supplemental dietary L-carnitine led to a significant reduction in serum cholesterol and very low-density lipoproteins in broiler chicks.

In harmony with our results, Nofal et al. (2006) showed that plasma concentrations of total lipid and cholesterol were reduced in response to added dietary L-carnitine in Gimmizah cocks. In breeding layers, Thiemel and Jelínek (2004) found that high-density lipoproteins. Also, Arslan et al. (2003) demonstrated that L-carnitine administration (via drinking water) to trukey ducklings did not affect serum concentrations of cholesterol, total lipid and glucose. oral administration with L-carnitine produced an increase in plasma level of glucose but decreased plasma levels of total protein, cholesterol and activity of alanine aminotransferase in broiler breeders.

Contrary to the present results, Parsaeimehr et al. (2014) found that adding L-carnitine in broiler chicken diet had no effect on blood levels of glucose, total protein, albumin, globulin cholesterol, low-density lipoproteins and

\section{CONCLUSION}

It can be concluded that eggs injected with biotin or L-Carnitine at the day $18^{\text {th }}$ of incubation could improve hatchability and subsequent broiler growth performance.

Table (1): Composition of starter and grower diets of broiler chicks

\begin{tabular}{|l|c|c|}
\hline Ingredient material (\%) & Starter diet & Grower diet \\
\hline Ground yellow corn & 60.50 & 67.80 \\
Soybean meal, 48\%CP & 30.80 & 22.00 \\
Corn gluten meal, 60\%CP & 4.00 & 3.20 \\
Sunflower oil & 0.00 & 2.30 \\
Ground limestone & 1.40 & 1.40 \\
Dicalcium phosphate & 2.30 & 2.30 \\
Salt (NaCl) & 0.35 & 0.35 \\
Vit.\&Min. Premix & 0.35 & 0.35 \\
DL-Methionine & 0.10 & 0.10 \\
L-Lysine.HCl & 0.10 & 0.10 \\
Coccidiostat & 0.10 & 0.10 \\
Total & 100 & 100 \\
\hline Calculated analysis (As fed basis, NRC, 1994) & 3157 \\
\hline ME; kcal/kg & 2934 & 18.35 \\
Crude protein, \% & 22.40 & 1.09 \\
Calcium, \% & 1.11 & 0.54 \\
Non-phytate phosphorus, \% & 0.55 & 0.94 \\
Lysine, \% & 1.19 & 0.42 \\
Methionine, \% & 0.47 & 0.73 \\
Methionine +Cystine, \% & 0.85 & 10000 , \\
\hline
\end{tabular}

Each $3 \mathrm{~kg}$ premix contains: Vit. A, $10000000 \mathrm{IU}$; vit. $\mathrm{D}_{3}$, $2000000 \mathrm{IU}$; vit. E, $10000 \mathrm{mg}$; vit. K, $1000 \mathrm{mg}$; vit. $\mathrm{B}_{1} 1000 \mathrm{mg}$; vit. $\mathrm{B}_{2}, 5000 \mathrm{mg}$; vit. $\mathrm{B}_{6}, 1500 \mathrm{mg}$; vit. $\mathrm{B}_{12}, 10 \mathrm{mg}$; folic acid, $1000 \mathrm{mg}$; biotin, $50 \mathrm{mg}$; pantothenic acid, $10000 \mathrm{mg}$; nicotinic, $30000 \mathrm{mg}$, Fe, $30000 \mathrm{mg}$; Mn,60000mg; $\mathrm{Zn}, 50000 \mathrm{mg}$; I, 300mg; Co,100mg; $\mathrm{Cu}, 4000 \mathrm{mg}$; Se, $100 \mathrm{mg}$ and $\mathrm{CaCO}_{3}$ up to $3000 \mathrm{~g}$. 
Sara Kh. Sherif et al.

Table (2): Effect of injecting eggs with saline, biotin and L-carnitine at four incubation on hatchability and hatching weight of broiler chicks .

\begin{tabular}{|c|c|c|c|c|}
\hline Treatments & \begin{tabular}{|c|} 
Total set \\
Hatchability $\%$
\end{tabular} & $\begin{array}{c}\text { fertile } \\
\text { Hatchability } \\
\%\end{array}$ & $\begin{array}{c}\text { Fertility } \\
\%\end{array}$ & $\begin{array}{c}\text { Hatching } \\
\text { chick } \\
\text { weight }(g)\end{array}$ \\
\hline 1 (Saline) & 60.83 & $73.31^{\mathrm{a}}$ & $84.00^{b}$ & 43.27 \\
\hline 2 (Biotin) & 62.17 & $70.78^{\mathrm{ab}}$ & $87.67^{\mathrm{a}}$ & 43.49 \\
\hline 3 (L-carnitine) & 61.17 & $68.39^{\mathrm{b}}$ & $89.33^{\mathrm{a}}$ & 43.45 \\
\hline SEM & 0.88 & 0.94 & 0.90 & 0.08 \\
\hline Significance level & NS & $* *$ & $* *$ & NS \\
\hline \multicolumn{5}{|l|}{ Time } \\
\hline 1 ( $1^{\text {st }}$ day $)$ & $41.33^{\mathrm{c}}$ & $47.14^{\mathrm{d}}$ & 87.78 & $43.5^{\mathrm{a}}$ \\
\hline $2\left(14^{\text {th }}\right.$ day $)$ & $68.00^{\mathrm{b}}$ & $78.87^{\mathrm{b}}$ & 86.22 & $43.1^{b}$ \\
\hline $3\left(16^{\text {th }}\right.$ day $)$ & $65.11^{\mathrm{b}}$ & $73.39^{c}$ & 88.67 & $43.4^{\mathrm{a}}$ \\
\hline $4\left(18^{\text {th }}\right.$ day $)$ & $71.11^{\mathrm{a}}$ & $83.91^{\mathrm{a}}$ & 85.33 & $43.6^{\mathrm{a}}$ \\
\hline SEM & 1.01 & 1.09 & 1.04 & 0.09 \\
\hline Significance level & $* *$ & $* *$ & NS & $*$ \\
\hline \multicolumn{5}{|l|}{$\begin{array}{l}\text { Interaction } \\
\text { (materials*Time) }\end{array}$} \\
\hline $1 * 1$ & 46.0 & 50.74 & 90.67 & 43.1 \\
\hline $1 * 2$ & 65.33 & 77.12 & 84.67 & 43.1 \\
\hline $1 * 3$ & 60.67 & 71.60 & 84.67 & 43.3 \\
\hline $1 * 4$ & 71.33 & 93.79 & 76.00 & 43.6 \\
\hline $2 * 1$ & 42.00 & 49.24 & 85.33 & 43.7 \\
\hline $2 * 2$ & 67.33 & 78.29 & 86.00 & 43.2 \\
\hline $2 * 3$ & 66.00 & 72.83 & 90.67 & 43.6 \\
\hline $2 * 4$ & 73.33 & 82.74 & 88.67 & 43.5 \\
\hline $3 * 1$ & 36.00 & 41.44 & 87.33 & 43.7 \\
\hline $3 * 2$ & 71.33 & 81.21 & 88.00 & 43.1 \\
\hline $3 * 3$ & 68.67 & 75.73 & 90.67 & 43.4 \\
\hline $3 * 4$ & 68.67 & 75.19 & 91.33 & 43.6 \\
\hline SEM & 1.75 & 1.89 & 1.80 & 0.16 \\
\hline Significance level & $* *$ & $* *$ & $* *$ & NS \\
\hline
\end{tabular}

Different superscripts in the same column indicate significant difference between means at $*$ $(\mathrm{P} \leq 0.05) . * *(\mathrm{P} \leq 0.01) . \mathrm{NS}=$ not siginificant. 
Sara Kh. Sherif et al.

Table (3): Effect of in ovo injection on performance of broiler chicks

\begin{tabular}{|c|c|c|c|c|c|}
\hline Treatments & $\begin{array}{c}\text { Initial } \\
\text { wt, } g\end{array}$ & $\begin{array}{c}\text { Final body } \\
\text { weight; } g\end{array}$ & $\begin{array}{c}\text { Total } \\
\text { weight } \\
\text { gain; } g\end{array}$ & $\begin{array}{l}\text { Total feed } \\
\text { intake; } g\end{array}$ & $\begin{array}{c}\text { Total feed } \\
\text { conversion }\end{array}$ \\
\hline 1 (Saline) & 43.27 & $2042^{c}$ & $1997^{\mathrm{c}}$ & 2925 & $1.465^{\mathrm{a}}$ \\
\hline 2 (Biotin) & 43.49 & $2161^{\mathrm{a}}$ & $2117^{\mathrm{a}}$ & 2932 & $1.386^{\mathrm{b}}$ \\
\hline 3 (L-carnitine) & 43.45 & $2092^{\mathrm{b}}$ & $2047^{\mathrm{b}}$ & 2964 & $1.448^{\mathrm{a}}$ \\
\hline SEM & 0.08 & 11.9 & 11.9 & 24.9 & 0.011 \\
\hline Significance level & NS & $* *$ & $* *$ & NS & $* *$ \\
\hline Time & & & & & \\
\hline 1 ( $1^{\text {st }}$ day $)$ & $43.5^{\mathrm{a}}$ & 2083 & 2038 & 2957 & 1.452 \\
\hline $2\left(14^{\text {th }}\right.$ day $)$ & $43.1^{b}$ & 2126 & 2081 & 2955 & 1.403 \\
\hline $3\left(16^{\text {th }}\right.$ day $)$ & $43.4^{\mathrm{a}}$ & 2099 & 2053 & 2956 & 1.441 \\
\hline $4\left(18^{\text {th }}\right.$ day $)$ & $43.6^{\mathrm{a}}$ & 2087 & 2041 & 2931 & 1.437 \\
\hline SEM & 0.09 & 13.9 & 13 & 28.7 & 0.013 \\
\hline Significance level & $*$ & NS & NS & NS & NS \\
\hline \multicolumn{6}{|l|}{$\begin{array}{l}\text { Interaction } \\
\text { (materials*Time) }\end{array}$} \\
\hline $1 * 1$ & 43.1 & 2034 & 1990 & 2929 & 1.472 \\
\hline $1 * 2$ & 43.1 & 2035 & 1991 & 2891 & 1.452 \\
\hline $1 * 3$ & 43.3 & 2042 & 1995 & 2946 & 1.477 \\
\hline $1 * 4$ & 43.6 & 2057 & 2011 & 2933 & 1.459 \\
\hline $2 * 1$ & 43.7 & 2141 & 2096 & 2982 & 1.424 \\
\hline $2 * 2$ & 43.2 & 2206 & 2161 & 2928 & 1.355 \\
\hline $2 * 3$ & 43.6 & 2167 & 2122 & 2908 & 1.370 \\
\hline $2 * 4$ & 43.5 & 2131 & 2087 & 2911 & 1.395 \\
\hline $3 * 1$ & 43.7 & 2072 & 2029 & 2959 & 1.459 \\
\hline $3 * 2$ & 43.1 & 2136 & 2092 & 2933 & 1.402 \\
\hline $3 * 3$ & 43.4 & 2088 & 2042 & 3012 & 1.475 \\
\hline $3 * 4$ & 43.6 & 2071 & 2026 & 2951 & 1.457 \\
\hline SEM & 0.16 & 23.9 & 23.8 & 49.8 & 0.023 \\
\hline Significance level & NS & NS & NS & NS & NS \\
\hline
\end{tabular}

Different superscripts in the same column indicate significant difference between means at $\mathrm{P} \leq 0.05$. 
Biotin, L-Carnitine, injection, Hatchability, Broilers, Growth performance.

Table (4): Effect of in ovo injection on carcass traits of broiler chickens

\begin{tabular}{|c|c|c|c|c|c|c|c|c|}
\hline Treatments & LBW & $\begin{array}{c}\text { Carc } \\
\text { ass } \\
\%\end{array}$ & $\begin{array}{c}\text { Liver } \\
\%\end{array}$ & $\begin{array}{l}\text { Gizza } \\
\text { rd \% }\end{array}$ & $\begin{array}{c}\text { Hear } \\
\text { t } \\
\%\end{array}$ & $\begin{array}{c}\text { Giblet } \\
\text { s } \\
\%\end{array}$ & $\begin{array}{c}\text { T E } \\
\mathbf{P} \\
\%\end{array}$ & $\begin{array}{c}\text { Abdomi } \\
\text { nal } \\
\text { Fat } \%\end{array}$ \\
\hline 1 (Saline) & 2007.5 & 70.06 & 2.15 & 1.17 & 0.45 & 3.77 & 73.83 & 1.2 \\
\hline 2 (Biotin) & 1966.3 & 71.51 & 2.37 & 1.07 & 0.42 & 3.85 & 75.37 & 1.29 \\
\hline 3 (L-carnitine) & 1930.4 & 73.45 & 2.27 & 1.09 & 0.38 & 3.74 & 77.18 & 1.27 \\
\hline SEM & 74.04 & 1.03 & 0.09 & 0.05 & 0.03 & 0.12 & 1.02 & 0.09 \\
\hline Significance level & NS & NS & NS & NS & NS & NS & NS & NS \\
\hline \multicolumn{9}{|l|}{ Time } \\
\hline 1 (1 $1^{\text {st }}$ day $)$ & 1908.3 & 71.36 & 2.31 & 1.11 & 0.37 & 3.79 & 75.15 & 1.31 \\
\hline $2\left(14^{\text {th }}\right.$ day $)$ & 1926.1 & 72.39 & 2.35 & 1.13 & 0.43 & 3.91 & 76.31 & 1.17 \\
\hline $3\left(16^{\text {th }}\right.$ day) & 1921.7 & 70.07 & 2.19 & 1.16 & 0.47 & 3.83 & 73.89 & 1.31 \\
\hline $4\left(18^{\text {th }}\right.$ day $)$ & 2116.1 & 72.87 & 2.19 & 1.02 & 0.39 & 3.61 & 76.47 & 1.23 \\
\hline SEM & 85.49 & 1.19 & 0.11 & 1.02 & 0.04 & 0.14 & 1.17 & 0.10 \\
\hline Significance level & NS & NS & NS & NS & NS & NS & NS & NS \\
\hline \multicolumn{9}{|l|}{$\begin{array}{l}\text { Interaction } \\
\text { (materials*Time) }\end{array}$} \\
\hline $1 * 1$ & 1840 & 69.58 & 2.12 & 1.08 & 0.41 & 3.61 & 73.19 & 1.26 \\
\hline $1 * 2$ & 1961.7 & 72.23 & 2.13 & 1.27 & 0.42 & 3.82 & 76.06 & 0.83 \\
\hline $1 * 3$ & 1985.0 & 67.25 & 2.25 & 1.27 & 0.59 & 4.12 & 71.37 & 1.53 \\
\hline $1 * 4$ & 2243.3 & 71.17 & 2.09 & 1.05 & 0.37 & 3.52 & 74.69 & 1.18 \\
\hline $2 * 1$ & 1980.0 & 71.09 & 2.53 & 1.11 & 0.37 & 4.02 & 75.11 & 1.52 \\
\hline $2 * 2$ & 1823.3 & 71.66 & 2.48 & 1.11 & 0.46 & 4.05 & 75.71 & 1.45 \\
\hline $2 * 3$ & 1958.3 & 71.06 & 2.22 & 1.11 & 0.46 & 3.79 & 74.86 & 1.20 \\
\hline $2 * 4$ & 2103.3 & 72.23 & 2.22 & 0.94 & 0.38 & 3.55 & 75.79 & 1.00 \\
\hline $3 * 1$ & 1905.0 & 73.40 & 2.28 & 1.13 & 0.34 & 3.76 & 77.16 & 1.14 \\
\hline $3 * 2$ & 1993.3 & 73.30 & 2.43 & 1.02 & 0.42 & 3.87 & 77.17 & 1.23 \\
\hline $3 * 3$ & 1821.7 & 71.88 & 2.11 & 1.11 & 0.36 & 3.57 & 75.46 & 1.19 \\
\hline $3 * 4$ & 2001.7 & 75.19 & 2.25 & 1.08 & 0.41 & 3.74 & 78.94 & 1.50 \\
\hline SEM & 148.1 & 2.05 & 0.19 & 0.10 & 0.07 & 0.25 & 2.04 & 0.18 \\
\hline Significance level & $\mathrm{NS}$ & $\mathrm{NS}$ & $\mathrm{NS}$ & $\mathrm{NS}$ & $\mathrm{NS}$ & $\mathrm{NS}$ & $\mathrm{NS}$ & $\mathrm{NS}$ \\
\hline
\end{tabular}


Sara Kh. Sherif et al.

Table (5): Effect of in ovo injection on blood plasma parameters of 1-day-old broiler chicks

\begin{tabular}{|c|c|c|c|c|c|c|c|}
\hline Treatments & $\begin{array}{l}\text { GLU. } \\
\text { mg/dl }\end{array}$ & $\begin{array}{l}\text { TP. } \\
\text { g/dl }\end{array}$ & $\begin{array}{l}\text { Chole. } \\
\text { mg/dl }\end{array}$ & $\begin{array}{l}\text { HDL } \\
\mathrm{mg} / \mathrm{dl}\end{array}$ & $\begin{array}{c}\text { LDL } \\
\mathrm{mg} / \mathrm{dl}\end{array}$ & $\begin{array}{c}\text { GPT } \\
\text { U/L }\end{array}$ & $\begin{array}{c}\text { GOT } \\
\text { U/L }\end{array}$ \\
\hline 1 (Saline) & 238.9 & 7.60 & 130.8 & 53.24 & 77.57 & 21.75 & 17.83 \\
\hline 2 (Biotin) & 253.6 & 7.49 & 129.2 & 49.89 & 79.35 & 22.67 & 15.92 \\
\hline 3 (L-carnitine) & 227.8 & 7.64 & 121.5 & 53.92 & 67.61 & 25.08 & 15.00 \\
\hline SEM & 8.84 & 0.15 & 7.17 & 1.28 & 7.44 & 1.20 & 1.08 \\
\hline Significance level & NS & NS & NS & NS & NS & NS & NS \\
\hline \multicolumn{8}{|l|}{ Time } \\
\hline 1 ( $1^{\text {st }}$ day $)$ & $271.2^{\mathrm{a}}$ & $7.99^{\mathrm{a}}$ & 113.6 & $58.59^{\mathrm{a}}$ & 55.02 & 27.85 & $18.11^{\mathrm{a}}$ \\
\hline $2\left(14^{\text {th }}\right.$ day $)$ & $219.1^{\mathrm{b}}$ & $7.69^{\mathrm{ab}}$ & 133.9 & $54.97^{\mathrm{a}}$ & 78.99 & 26.89 & $18.56^{\mathrm{a}}$ \\
\hline $3\left(16^{\text {th }}\right.$ day $)$ & $240.7^{\mathrm{b}}$ & $7.28^{b}$ & 138.4 & $49.63^{\mathrm{b}}$ & 88.73 & 28.11 & $14.44^{b}$ \\
\hline $4\left(18^{\text {th }}\right.$ day $)$ & $229.4^{\mathrm{b}}$ & $7.33^{b}$ & 122.8 & $46.21^{\mathrm{b}}$ & 76.64 & 28.56 & $13.89^{b}$ \\
\hline SEM & 10.2 & 0.17 & 8.28 & 1.48 & 8.59 & 1.39 & 1.25 \\
\hline Significance level & $* *$ & $*$ & NS & $* *$ & NS & NS & $*$ \\
\hline \multicolumn{8}{|l|}{$\begin{array}{l}\text { Interaction } \\
\text { (materials*Time) }\end{array}$} \\
\hline $1 * 1$ & 275.3 & 8.41 & 111.9 & 65.54 & 46.4 & 28.11 & 18.00 \\
\hline $1 * 2$ & 208.3 & 7.63 & 122.0 & 57.85 & 64.2 & 26.33 & 18.33 \\
\hline $1 * 3$ & 231.3 & 7.24 & 149.7 & 44.95 & 104.7 & 29.67 & 15.33 \\
\hline $1 * 4$ & 240.7 & 7.12 & 139.6 & 44.62 & 95.0 & 27.00 & 19.67 \\
\hline $2 * 1$ & 309.3 & 7.45 & 119.5 & 54.78 & 64.7 & 29.33 & 18.67 \\
\hline $2 * 2$ & 210.3 & 7.85 & 139.6 & 51.26 & 88.4 & 27.67 & 19.33 \\
\hline $2 * 3$ & 264.7 & 7.43 & 134.6 & 47.08 & 87.5 & 27.33 & 14.00 \\
\hline $2 * 4$ & 230.0 & 7.25 & 123.3 & 46.44 & 76.8 & 31.67 & 11.67 \\
\hline $3 * 1$ & 229.0 & 8.12 & 109.4 & 55.47 & 53.9 & 28.33 & 17.67 \\
\hline $3 * 2$ & 238.7 & 7.61 & 140.3 & 55.80 & 84.5 & 26.67 & 18.00 \\
\hline $3 * 3$ & 225.7 & 7.18 & 130.8 & 56.86 & 73.9 & 27.33 & 14.00 \\
\hline $3 * 4$ & 217.7 & 7.63 & 105.7 & 47.56 & 58.1 & 27.00 & 10.33 \\
\hline SEM & 17.67 & 0.29 & 14.35 & 2.56 & 14.88 & 2.40 & 2.16 \\
\hline Significance level & NS & NS & NS & $* *$ & NS & NS & NS \\
\hline
\end{tabular}

Different superscripts in the same column indicate significant difference between means at $\mathrm{P} \leq 0.05$.

GLU. = glucose $; \mathrm{TP} .=$ total protein Chole.$=$ total cholesterol $\mathrm{HDL}=$ high density lipoprotein; LDL=low density lipoprotein; GPT = glutamate pyruvate transaminase; GOT= glutamic oxaloacetic transaminase 
Sara Kh. Sherif et al.

Table (6): Effect of in ovo injection on belood plasma constituents of broiler chicks

\begin{tabular}{|c|c|c|c|c|c|c|c|c|c|c|}
\hline Treatments & $\begin{array}{c}\text { GLU } \\
\text { mg/dl }\end{array}$ & $\begin{array}{c}\text { TP } \\
\text { g/dl }\end{array}$ & $\begin{array}{l}\text { Chol } \\
\text { mg/dl }\end{array}$ & $\begin{array}{l}\text { HDL } \\
\mathrm{mg} / \mathrm{dl}\end{array}$ & $\begin{array}{c}\text { LDL } \\
\mathrm{mg} / \mathrm{dl}\end{array}$ & $\begin{array}{c}\text { GPT } \\
\text { U/L }\end{array}$ & $\begin{array}{l}\text { GOT } \\
\text { U/L }\end{array}$ & $\begin{array}{c}\mathrm{TL} \\
\mathrm{mg} / \mathrm{dl}\end{array}$ & $\begin{array}{c}\mathrm{T3} \\
\mathrm{ng} / \mathrm{dl}\end{array}$ & $\begin{array}{c}\mathrm{T} 4 \\
\mathrm{ng} / \mathrm{dl}\end{array}$ \\
\hline 1 (Saline) & 246.5 & 6.39 & 116.7 & 57.80 & $58.85^{\mathrm{a}}$ & 43.58 & 30.17 & $835.49^{\mathrm{a}}$ & $3.59^{b}$ & $10.58^{\mathrm{b}}$ \\
\hline 2 (Biotin) & 242.0 & 6.47 & 112.8 & 58.56 & $54.26^{\mathrm{b}}$ & 42.67 & 28.83 & $828.24^{\mathrm{a}}$ & $4.19^{\mathrm{a}}$ & $11.87^{\mathrm{a}}$ \\
\hline 3 (L-carnitine) & 242.4 & 6.41 & 114.8 & 57.79 & $57.04^{\mathrm{ab}}$ & 45.25 & 30.08 & $786.17^{\mathrm{b}}$ & $3.89^{\mathrm{ab}}$ & $12.42^{\mathrm{a}}$ \\
\hline SEM & 11.56 & 0.04 & 1.33 & 0.85 & 1.19 & 1.5 & 1.11 & 15.67 & 0.14 & 0.29 \\
\hline Significance level & NS & NS & NS & NS & $*$ & NS & NS & * & - & ** \\
\hline \multicolumn{11}{|l|}{ Time } \\
\hline $1\left(1^{\text {st }}\right.$ day $)$ & $222.9^{b}$ & 6.29 & 113.7 & $61.29^{\mathrm{a}}$ & $52.38^{\mathrm{b}}$ & 40.89 & $31.00^{\mathrm{a}}$ & $734.2^{b}$ & $3.89^{\mathrm{ab}}$ & $8.12^{\mathrm{c}}$ \\
\hline $2\left(14^{\text {th }}\right.$ day $)$ & $270.0^{\mathrm{a}}$ & 6.49 & 115.3 & $57.65^{\mathrm{b}}$ & $57.66^{\mathrm{a}}$ & 43.00 & $32.00^{\mathrm{a}}$ & $823.1^{\mathrm{a}}$ & $3.73^{\mathrm{b}}$ & $13.38^{\mathrm{a}}$ \\
\hline $3\left(16^{\text {th }}\right.$ day $)$ & $257.8^{\mathrm{ab}}$ & 6.45 & 115.9 & $58.07^{\mathrm{b}}$ & $57.90^{\mathrm{a}}$ & 46.40 & $28.78^{\mathrm{ab}}$ & $812.7^{\mathrm{a}}$ & $4.31^{\mathrm{a}}$ & $12.28^{\mathrm{b}}$ \\
\hline $4\left(18^{\text {th }}\right.$ day $)$ & $223.9^{\mathrm{b}}$ & 6.44 & 114.1 & $55.19^{b}$ & $58.93^{\mathrm{a}}$ & 45.00 & $27.00^{\mathrm{b}}$ & $832.8^{\mathrm{a}}$ & $3.65^{\mathrm{b}}$ & $12.72^{\mathrm{ab}}$ \\
\hline SEM & 13.35 & 0.05 & 1.54 & 0.99 & 1.38 & 1.74 & 1.28 & 18.09 & 0.16 & 0.34 \\
\hline Significance level & $*$ & NS & NS & $* *$ & * & NS & * & $* *$ & * & $* *$ \\
\hline \multicolumn{11}{|l|}{$\begin{array}{l}\text { Interaction } \\
\text { (materials*Time) }\end{array}$} \\
\hline $1 * 1$ & 216.0 & 6.06 & 112.5 & 60.72 & 52.23 & 43.33 & 32.67 & 748.3 & 1.60 & 5.62 \\
\hline $1 * 2$ & 280.7 & 6.48 & 116.1 & 59.97 & 56.13 & 43.33 & 31.33 & 814.6 & 4.59 & 11.87 \\
\hline $1 * 3$ & 274.3 & 6.50 & 123.4 & 57.57 & 65.83 & 45.00 & 27.67 & 823.7 & 4.30 & 10.50 \\
\hline $1 * 4$ & 215.0 & 6.52 & 114.6 & 53.38 & 61.20 & 42.67 & 29.00 & 815.3 & 3.90 & 14.34 \\
\hline $2 * 1$ & 220.3 & 6.54 & 110.9 & 62.17 & 48.76 & 37.33 & 27.67 & 730.9 & 4.96 & 9.23 \\
\hline $2 * 2$ & 257.7 & 6.57 & 115.9 & 58.53 & 57.37 & 43.00 & 34.33 & 818.9 & 3.82 & 13.37 \\
\hline $2 * 3$ & 254.3 & 6.39 & 110.9 & 59.58 & 51.28 & 44.00 & 26.33 & 827.3 & 4.39 & 14.84 \\
\hline $2 * 4$ & 235.7 & 6.38 & 113.6 & 53.97 & 59.64 & 46.33 & 27.00 & 767.5 & 3.62 & 10.06 \\
\hline $3 * 1$ & 232.3 & 6.27 & 117.6 & 61.43 & 56.14 & 42.00 & 32.67 & 723.3 & 5.10 & 9.51 \\
\hline $3 * 2$ & 271.7 & 6.44 & 113.9 & 54.46 & 59.48 & 42.67 & 30.33 & 734.6 & 2.79 & 14.91 \\
\hline $3 * 3$ & 244.7 & 6.46 & 113.7 & 57.05 & 56.61 & 50.33 & 32.33 & 787.2 & 4.24 & 11.5 \\
\hline $3 * 4$ & 221.0 & 6.44 & 114.2 & 58.21 & 55.95 & 46.00 & 25.00 & 762.5 & 3.42 & 1377 \\
\hline SEM & 23.12 & 0.09 & 2.66 & 1.71 & 2.39 & 3.01 & 2.22 & 31.35 & 0.28 & 0.59 \\
\hline Significance level & NS2 & $*$ & NS & NS & $*$ & NS & NS & $* *$ & $* *$ & $* *$ \\
\hline
\end{tabular}

Different superscripts in the same column indicate significant difference between means at $\mathrm{P} \leq 0.05$.

GLU. $=$ glucose TP.$=$ total protein; Chole.$=$ total cholesterol; $\mathrm{HDL}=$ high density lipoprotein; LDL=low density lipoprotein; GPT = glutamate pyruvate transaminase; GOT= glutamic oxaloacetic transaminase; $\mathrm{TL}=$ total lipid; $\mathrm{T} 3=$ triiodothyronine; $\mathrm{T} 4=$ thyroxine 
Sara Kh. Sherif et al.

\section{REFERENCES}

Abdel-Fattah, S. A.; El-Daly, E. F. and Ali, N. G. M., 2014. Growth performance, immune response, serum metabolites and digestive enzyme activities of Japanese quail fed supplemental L-Carnitine. Global Vet., 12: 277-286.

Abdulateef S. and Al-Bayar M. 2013. The effect of injecting hatching eggs with different concentrations of biotin on the embryonic development of the broiler chicken. Conference: Poultry Science Association Annual Meeting, San Diego, California, USA, Poultry Science Vol. 92 :156-162.

Ahmed, M. A. M.; El-Badry, A. S. O.; Samya E. Ibrahim and Seif El-naser, M. I. 2017. Role of biotin in improving hatchability and physiological status of turkey chicks as affected by age of flock. Egypt. Poult. Sci. Vol (37) (III): 987-1012.

Arslan, C.; Itil, M. C. and Saatc, M. 2003. Effects of L-carnitine administration on growth performance, carcass traits, blood serum parameters and abdominal fatty acid composition of ducks. Arch. Anim. Nutr., 57: 381 388.

Barker, D. L. and Sell, J. L. 1994. Dietary carnitine did not influence performance and carcass composition of broiler chickens and young turkeys fed low or high fat diets. Poultry Science, 73(2): 281-287.

Bremer, J. 1983. Carnitine-metabolism and functions. Physiol. Rev., 63: 14201480.

Bhanja, S. K.; Mandal, A. B.; Agarwal, S. K.; Majumdar, S. and Bhattacharyya, A. 2007. Effect of in ovo injection of vitamins on the chick weight and post hatch growth performance in broiler chickens. Pages
143-146 in Proc. 16th European Symp. Poult. Nutr., Strasbourg, France.

Bhanja, S. K.; Mandal, A. B.; Agarwal, S. $\quad$ K.; $\quad$ Majumdar, S.; Bhattacharyya, A. and Kadam, M. M. 2008. In ovo glucose injection for higher chick weight and gastrointestinal tract development. Indian Veterinary Journal 85: 289-92.

Calnek, B.; Barnes, H.; Beard, C. and Yoder, H. 1997. "Diseases of poultry. Ames," Iowa, USA: Iowa State University Press.

Dooley, M.; Peebles, E. D.; Zhai, W.; Mejia, L.; Zumwalt, C. D. and Corzo, A. 2011. Effects of 1-carnitine via in ovo injection with or without 1carnitine feed supplementation on broiler hatchability and post hatch performance. J. Appl. Poult. Res. 20:491-497. doi: 10.3382/japr.201000280

Duncan, D. B. 1995. The multiple range and multiple F. tests. Biometrics, 11:142.

Jensen, J. F. 1984. "Method of dissection of broiler carcasses and description of parts: terms used for parts of poultry in different languages," World's Poultry Science Association European Federation, Working Group V.

Ibrahim, N. S.; Wakwak M. M. and Khalifa H. H. 2012. Effect of in ovo injection of some nutrients and vitamins upon improving hatchability and hatching performance of ostrich embryos. Egyptian Poult. Sci. 32: 981994.

Keralapurath, M. M.; Corzo, A.; Pulikanti, R.; Zhai, W. and Peebles, E. D. 2010a. Effects of in ovo injection of L-carnitine on hatchability and subsequent broiler performance and slaughter yield. Poultry Science, 89(7) :1497-1501. 
Biotin, L-Carnitine, injection, Hatchability, Broilers, Growth performance.

Keralapurath, M. M.; Keirs, R. W.;

Corzo, A.; Bennett, L. W.;

Pulikanti, R. and Peebles, E. D.

2010b. Effects of in ovo injection of 1carnitine on subsequent broiler chick tissue nutrient profiles. Poult. Sci. 89:335-341.

Lettner, F.; Zollitsch, W. and Halbmayer, E. 1992. L-Carnitine in broiler diets. Bodenkultur, 43(2): 161167.

McMahon, R. J. 2002. Biotin in metabolism and molecular biology. Annu. Rev. Nutr. 22:221-239.

Memon, M.; Abbasi, I. H. R.; Sahito, H. A.; Abbasi, F.; Sanjrani, M. I.; and Memon, A. 2014. Effect of biotin as a feed additive on the growth of broiler. International Journal of Innovative Agriculture \& Biology Research 4, 17-25.

Nofal, M. E.; Samak, H. R.; Mariey, Y. A. and Mahamud, R. M. 2006. Production performance and serum constituents of aged Gimizah hens as affected by dietary supplementation with L -carntine. Egypt. Poult. Sci., 26:1269-1283.

Nouboukpo, K. E.; Tona, K.; Kamers, B.; Everaert, N.; Willemsen, H.; Onagbesan, O. M.; Gbeassor, M. and Decuypere, E. 2010. Effects of in ovo administration of L-carnitine on hatching events and juvenile performance of layer-type chick. Int. J. Poultry Sci., 9(10): 980-983.

NRC; National Research Council, 1994. Nutrient Requirements of Poultry. $9^{\text {th }}$ revised Ed. National Academy press, Washington, DC., USA.

Oladele, O. A.; Adeboye, F.; Richard, S. and Zainob, H. 2011. Growth response, carcass yield and serum biochemistry of broiler chickens fed with supplemental L-carnitine in feed or drinking water. Journal of Poultry Science, 48(4): 223-228.

Parsaeimehr, K.; Afrouziyeh, M. and Hoseinzadeh, S. 2014. The Effects of L-carnitine and different levels of animal fat on performance, carcass characteristics, some blood parameters and immune response in broiler chicks. Iranian Journal of Applied Animal Science, 4(3): 561-566.

Rabie, M. H. and Szilagyi, M. 1998. Effect of L-carnitine supplementation of diets differing in energy levels on performance, abdominal fat content, and yield and composition of edible meat of broilers. British Journal of Nutrition, 80(4): 391-400.

Rabie, M. H.; Szilagyi, M. and Gippert, T. 1997. Influence of supplemental dietary L-carnitine on performance and egg quality of pullets during the early laying period. Állattenyésztés és Takarmányozás 46(5): 457-468.

Rezaei, M.; Attar, A.; Ghodratnama, A. and Kermanshahi, H. 2007. Study the effects of different levels of fat and L-carnitine on performance, carcass characteristics and serum composition of broiler chicks. Pak. J. Biol. Sci., 10: 1970-1976.

Robel, E. J. 2002. Assessment of dietary and egg injected biotin, pyridoxine and folic acid on turkey hatchability: folic acid and poult weight. World's Poult. Sci. J. 58:305-315.

Salmanzadeh, M.; Ebrahimnezhad, Y. and Shahryar, H. A. 2012. Effects of in ovo administration of L-carnitine on hatchability, subsequent performance, carcass traits and blood cholesterol of turkey poults. Revue Méd. Vét., 163(10): 448-453.

Salmanzadeh, M.; Ebrahimnezhad, Y. and Shahryar, H. A. 2013. The 
Sara Kh. Sherif et al.

effects of in ovo injection of Lcarnitine on hatching traits, growth performance, and carcass characteristics of turkey poults. Bull. Env. Pharmacol. Life Sci., 2(11): 125128.

Sarica, S.; Corduk, M. and Kilinc, K. 2005. The Effects of dietary Lcarnitine supplementation on growth performance, carcass traits, and composition of edible meat in Japanese quail (Coturnix coturnix japonica). J. Appl. Poultry Res., 14(4): 709-715.

SAS 2004. SAS® User's Guide. Statistics version 10th ed., SAS Institute Inc., NC. USA.

Shafey, T. M.; Al-Batshan, H. A.; AlOwaimer, A. N. and Al-Samawei, K. A. 2010. Effects of in ovo administration of L-carnitine on hatchability performance, glycogen status and insulin-like growth factor-1 of broiler chickens. British Poultry Science, 51(1): 122-131.

Spectrum Diagnostic kits S.A.E., Egyptian company of biotechnology 2016. Spectrum diagnostic Kits.

Thiemel, J. and Jelínek, P. 2004. The effect of carnitine on hatching rate and metabolic profile of blood in breeding layers. Czech J. Anim. Sci., 49, 517523.
Vieira, S. 2007. Chicken embryo utilization of egg micronutrients. Brazilian Journal of Poultry Science 9, 1-8.

Wang, Y. W.; Ning, D.; Peng, Y. Z. and Guo, Y. M. 2013. Effects of Dietary L-carnitine Supplementation on Growth Performance, Organ Weight, Biochemical Parameters and Ascites Susceptibility in Broilers Reared Under Low-temperature Environment. Asian-Australas J Anim Sci. 2013 Feb; 26(2):233-240. doi: 10.5713/ajas.2012.12407

Xu, Z.R.; Wang, M. Q.; Mao, H. X.; Zhan, X. A. and Hu, C. H. 2003. Effects of L-carnitine on growth performance, carcass composition, and metabolism of lipids in male broilers. Poultry Science, 82(3): 408-413.

Zhai, W.; Neuman, S. L.; Latour, M. A. and Hester, P. Y. 2008. The effect of in ovo injection of L-Carnitine on hatchability of White Leghorns. Poultry Science, 87(3): 569-572. 
Biotin, L-Carnitine, injection, Hatchability, Broilers, Growth performance.

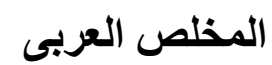

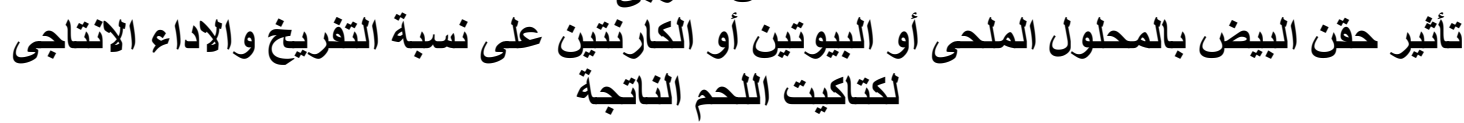

$$
\begin{aligned}
& \text { سارة خليل شريف ـ فوزى صديق عبد الفتاح اسماعيل ـ السيد ابراهيم الباسل - زياد محمد العوضى قلبة } \\
& \text { قسم انتاج الدو اجن - كلبة الزر اعة - جامعة المنصورة الميم الباعل }
\end{aligned}
$$

أجريت هذه الدر اسة لمعرفة تأثير حقن البيض بكل من البيوتين و الكارنيتين في أربعة أعمار تفريخ مختلفة

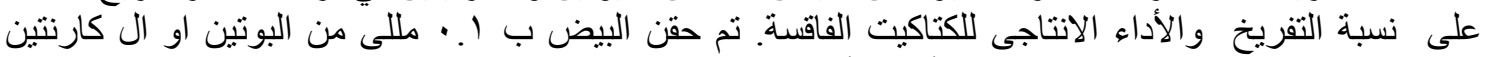

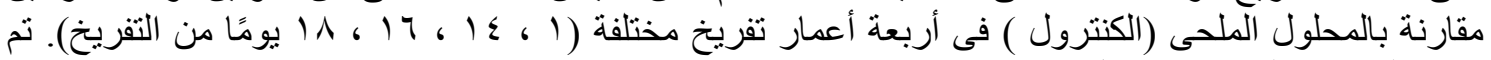

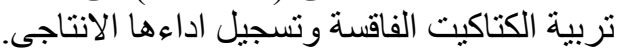

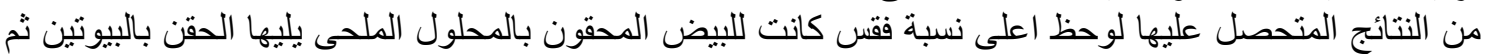

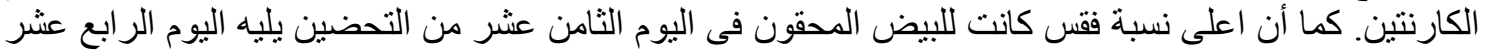

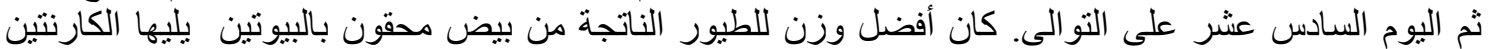

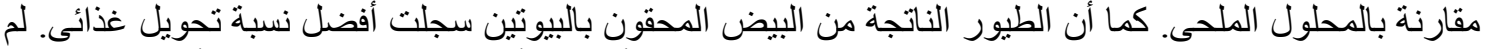

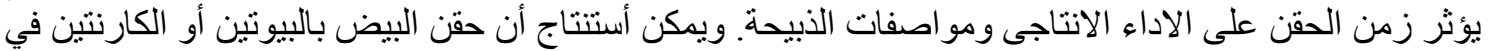
اليوم الثامن عشر من التفريخ يحسن من نسبة الفقس والاداء الأناء الإنتاجي للطيور الناتجة. 